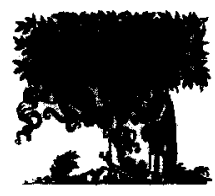

ANALYTICA

CHIMICA

ACTA

\title{
Dual enzyme labels for simultaneous heterogeneous enzyme- linked competitive binding assays
}

\author{
Jeanette M. Buckwalter, Xuan Guo, Mark E. Meyerhoff * \\ Department of Chemistry, University of Michigan, Ann Arbor, MI 48109-1055, USA
}

Received 7 December 1993; revised manuscript received 2 June 1994

\begin{abstract}
The use of two enzyme labels in a dual analyte simultaneous heterogeneous enzyme-linked competitive binding assay is examined. Reaction conditions for monitoring glucose-6-phosphate dehydrogenase (G6PDH) and $\beta$-galactosidase ( $\beta$-gal) activities are found which enable the independent measurement of each enzyme activity in the presence of the other. The two enzymes are used as labels in the development of a model simultaneous heterogeneous competitive binding assay for detecting the biotin and vitamin $\mathbf{B}_{12}$ content of vitamin tablets. The simultaneous assay is shown to exhibit analytical dose-response characteristics comparable to those of the single analyte assays. The potential use of the G6PDH/ $\beta$-gal enzyme pair for devising other dual analyte competitive and non-competitive binding assays is discussed.
\end{abstract}

Keywords: Enzymatic mcthods; Simultaneous detection; Enzyme-linked binding assays; Vitamins; Glucose-6-phosphatc dehydrogenase; $\beta$ Galactosidase

\section{Introduction}

Since their introduction in 1971, enzyme immunoassays have become important analytical tools for the determination of biomolecules at trace levels $[1,2]$. Enzymes are attractive as labels for binding assays because of their ease in handling and innate signal amplification qualities [3]. It has also been shown that naturally occurring binding proteins may be used in place of selective antibodies in such methods. This is especially useful when the analyte to be assayed is an endogenous molecule to which raising antibodies is difficult, e.g., vitamins [4-6].

Recently, interest has focused on developing binding assays that can analyze more than one analyte at a time in the same assay mixture. Indeed, many clinically

\footnotetext{
* Corresponding author.
}

important species are commonly determined in pairs, e.g., folate/vitamin $B_{12}, \mathrm{TSH} /$ free $T_{4}$, etc. $[3,7,8]$, where quantitative data for both species is required for diagnostic purposes. The advantages of performing simultaneous analyses are a decreased reagent and sample volume requirement and an enhanced analytical efficiency which can lead to a decrease in assay cost. Simultaneous heterogeneous binding assays (solidphase assays) have been carried out previously using dual radioisotope and fluorophore labels [9-11]. There have also been attempts to adapt enzyme-labeled assays to a simultaneous format; however, these previous assays were based on sequential rather than simultaneous enzyme reactions (i.e., the second enzyme was assayed after measuring the first) $[3,12]$. To date, there has been no published report describing a system in which a truly simultaneous assay for two analytes is performed by monitoring the rate of two enzyme reac- 
tions concurrently in the same sample mixture. This may be due to the difficulty in choosing compatible enzymes and reaction conditions in which the substrates or products can be quantitated accurately and simultaneously in the same solution.

The initial purpose of this work was to screen a number of potential enzyme pairs for use in truly simultaneous enzyme-linked binding assays. The criteria used for these evaluations included [3,13-15]: (a) the purity and specific activity of the enzymes; (b) their stability; (c) the ease of preparing the required conjugates of each enzyme; (d) the ability to resolve products/substrates spectrophotometrically for simultaneous kinetic assays; (e) similar $\mathrm{pH}$ optima for the two enzymes; and (f) reaction conditions required for one enzyme (e.g., given cofactors, metal ions, etc.) do not greatly affect the activity of the second enzyme. Of the various enzyme pairs examined, glucose-6-phosphate dehydrogenase (G6PDH) and $\beta$-galactosidase ( $\beta$ gal) were found to be suitable for use in a simultaneous heterogeneous assay format. In this paper, the optimized reaction conditions for dual enzyme measurements is reported. In addition, a model simultaneous enzyme-linked competitive binding assay for the detection of vitamin $B_{12}$ and biotin is demonstrated using G6PDH and $\beta$-gal as the enzyme labels.

\section{Experimental}

\subsection{Apparatus and reagents}

Enzyme activities were measured with a GilfordStasar-III spectrophotometer equipped with a vacuumoperated sampling system and temperature-controlled cuvette (maintained at $25^{\circ} \mathrm{C}$ ). This spectrophotometer was connected to a Syva CP-5000 EMIT clinical processor for automatically setting the reading intervals and recording the absorbance values. A Perkin-Elmer Lambda Array 3840 UV-visible spectrophotometer operated by a Model 7300 professional computer was used for measuring the changes in absorbance at two wavelengths during the simultaneous assays. An IEC Centra-7R refrigerated centrifuge $\left(4^{\circ} \mathrm{C}\right)$ was used for all centrifugation steps.

Glucose-6-phosphate dehydrogenase (G6PDH) from $L$. mesenteroides, $\beta$-galactosidase ( $\beta$-gal) from $E$. coli, glucose-6-phosphate (G6P), $\beta$-nicotinamide adenine dinucleotide (NAD), $o$-nitrophenyl galactopyranoside (ONPG), biotinylated $\beta$-galactosidase $(\beta$ gal-biotin), avidin from egg white, porcine non-intrinsic factor (R-protein), vitamin $B_{12}$, biotin, $N$-hydroxysuccinimide, $3,3^{\prime}$-diethylaminopropyl carbodiimide, dithiothreitol (DTT), as well as other chemicals were purchased from Sigma (St. Louis, MO). The vitamin tablets, multivitamin/multimineral and B-100, were commercially available from Kroger (Cincinnati, $\mathrm{OH}$ ).

The optimal dual assay buffer consisted of $0.05 \mathrm{M}$ tris(hydroxymethyl)aminomethane-hydrochloric acid (Tris- $\mathrm{HCl}$ ), $\mathrm{pH} \mathrm{7.8,} \mathrm{containing} 0.10 \mathrm{M} \mathrm{NaCl}$, $0.002 \mathrm{M} \mathrm{MgCl}_{2}, 0.1 \%(\mathrm{w} / \mathrm{v})$ gelatin, and $0.01 \%$ $(\mathrm{w} / \mathrm{v}) \mathrm{NaN}_{3}$. All substrate, standard solutions, and dilutions were prepared in assay buffer. All incubations were performed at room temperature.

Independent liquid chromatographic (LC) determinations of the $B_{12}$ and biotin content of the given vitamin preparations were carried out using a Waters 600 E solvent delivery system (Marlborough, MA), a Waters 486 tunable absorbance detector, and a Hewlett Packard 3396 Series II integrator. A reversed-phase $C_{18}$ column $(15 \times 4.6 \mathrm{~mm}$ i.d.) from Supelco (Bellefonte, PA) was employed for both assays.

\subsection{Simultaneous analysis of $\beta$-gal and G6PDH}

To determine the influence of the G6PDH reaction on $\beta$-gal activity, the linearity of $\beta$-gal activity was measured in the presence of G6P/NAD and the G6PDH reaction running simultaneously. In a final volume of $1 \mathrm{ml}, 25-250 \mathrm{mU}$ of $\beta$-gal, $1.7 \mathrm{mM}$ ONPG, 0.5 $\mathrm{mM} \mathrm{G6P,} 3.2 \mathrm{mM} \mathrm{NAD}$, and $55 \mathrm{mU}$ G6PDH or assay buffer were mixed together. The $\beta$-gal activity was determined by measuring the rate of absorbance change at $415 \mathrm{~nm}$ over a $4 \mathrm{~min}$ period.

To determine the linearity of G6PDH activity in the presence of ONPG and the $\beta$-gal reaction, $2.2-22 \mathrm{mU}$ of G6PDH, $0.5 \mathrm{mM}$ G6P, $3.2 \mathrm{mM}$ NAD, $1.7 \mathrm{mM}$ ONPG, and $0.625 \mathrm{U}$ of $\beta$-gal or assay buffer were mixed together and brought to a final volume of $1 \mathrm{ml}$. The G6PDH activity was determined by measuring the rate of absorbance change at $347 \mathrm{~nm}$ over a $4 \mathrm{~min}$ period. 


\subsection{Preparation of conjugates}

Carboxylated vitamin $B_{12}$ was prepared according to the method suggested by Armitage et al. [16]. The monocarboxylic derivatives were isolated using ionexchange chromatography [17]. Further purification to isolate the e-monocarboxyl derivative was not necessary since $\mathrm{R}$-protein does not differentiate among the three monocarboxylic isomers of vitamin $B_{12}[18-20]$.

G6PDH-vitamin $B_{12}$ conjugates were prepared using a modified $N$-hydroxysuccinimide method as described previously in the literature [21-23]. A G6PDH-vitamin $B_{12}$ conjugate useful for the proposed simultaneous assay system was prepared containing an average of 1.0 vitamin $B_{12}$ molecules per enzyme as determined by analysis of the absorbance spectra [21]. This enzyme conjugate possessed 55\% of its original catalytic activity after conjugation.

The $\beta$-gal-biotin conjugate was prepared by Sigma via the reaction of 3-( $N$-maleimido-propionyl) biocytin with $\beta$-gal. This is a thiol-specific biotinylating reagent which incorporates a long spacer group required for efficient avidin/biotin binding [24,25]. According to Sigma, there are 3.5 biotin molecules attached per enzyme.

\subsection{Preparation of solid phase $R$-protein and avidin}

Solid phase R-protein was prepared by reacting 2000 $\mathrm{U}$ of R-protein with $360 \mathrm{mg}$ of $\mathrm{CNBr}$-activated Sepharose $4 \mathrm{~B}$ according to the method suggested by the manufacturer of the Sepharose [26]. The protein and solid phase were mixed for $2 \mathrm{~h}$ at room temperature in an end-over-end mixer. The excess active sites were blocked by adding $1 \mathrm{M}$ glycine and mixing overnight at $4^{\circ} \mathrm{C}$. Non-specifically adsorbed protein was removed by alternately washing with $0.10 \mathrm{M} \mathrm{NaHCO}_{3}, 0.50 \mathrm{M}$ $\mathrm{NaCl}, \mathrm{pH} 8.3$ and $0.10 \mathrm{M}$ sodium acetate-acetic acid, $0.50 \mathrm{M} \mathrm{NaCl}, \mathrm{pH} 4.0$. The particles were stored in assay buffer at a 1:20 (packed bead $v / v$ ) dilution. Solid phase avidin was prepared by reacting $13.2 \mathrm{U}$ of avidin with $1000 \mathrm{mg}$ of $\mathrm{CNBr}$-activated Sepharose 4B using this same procedure.

\subsection{Preparation of vitamin tablets}

Ten vitamin tablets were ground and the amount equivalent to one tablet was dissolved in $50 \mathrm{ml}$ deion- ized water in a $50 \mathrm{ml}$ polypropylene centrifuge tube. The solution was vigorously shaken for $30 \mathrm{~min}$ at room temperature. The suspension was then centrifuged at $3200 \mathrm{rpm}$ for $15 \mathrm{~min}$. The supernatant was saved and the solid was again washed with $50 \mathrm{ml}$ deionized water and $50 \mathrm{ml} 0.04 \mathrm{M} \mathrm{NaOH}$ with centrifugation between washes and subsequent pooling of the supernatant solutions. The solution was brought to a final volume of $200 \mathrm{ml}$ with deionized water containing $0.01 \%(\mathrm{w} / \mathrm{v})$ $\mathrm{NaN}_{3}$ to prevent bacterial growth, and was stored at $4^{\circ} \mathrm{C}$ in the dark.

To prepare spiked samples for recovery studies, 44.5 $\mu \mathrm{l}$ of $0.10 \mathrm{mM}$ vitamin $B_{12}$ and $123 \mu l$ of $1.0 \mathrm{mM}$ biotin standards or $133 \mu \mathrm{l}$ of $0.10 \mathrm{mM}$ vitamin $B_{12}$ and 368 $\mu \mathrm{l}$ of $1.0 \mathrm{mM}$ biotin standards were added to the vitamin powder. The samples were then treated as described above.

The determinations of biotin and vitamin $B_{12}$ in the two vitamin tablet preparations by $\mathrm{LC}$ were carried out by adapting the methods reported previously by Crivelli et al. [33] and Dalbacke [37], respectively.

\subsection{Single analyte assays}

For single vitamin $B_{12}$ assays, $50 \mu l$ of R-protein particles, $50 \mu \mathrm{l}$ of $0.672 \mathrm{M}$ DTT, $100 \mu \mathrm{l}$ of vitamin $\mathrm{B}_{12}$ standard or unknown, and $500 \mu \mathrm{l}$ of assay buffer were added to conical polypropylene culture tubes previously coated overnight with a $1 \%$ gelatin solution. The solutions were incubated for $30 \mathrm{~min}$ with mixing. Next, $100 \mu$ of $2.0 \times 10^{-8} \mathrm{M}$ G6PDH-vitamin $\mathrm{B}_{12}$ conjugate and $200 \mu \mathrm{l}$ of assay buffer were added, and the solutions were incubated for $60 \mathrm{~min}$. The solid phase was then washed three times with $2 \mathrm{ml}$ of assay buffer to remove any unbound analyte or conjugate. Finally, $100 \mu \mathrm{l}$ of $0.010 \mathrm{M}$ G6P and $0.063 \mathrm{M}$ NAD solution and $800 \mu \mathrm{l}$ of assay buffer were added and allowed to mix for 60 $\mathrm{min}$. The solutions were centrifuged and the absorbance of the supernatant was determined at $347 \mathrm{~nm}$.

For single biotin assays, $50 \mu \mathrm{l}$ of avidin solid phase, $50 \mu \mathrm{l}$ of $0.672 \mathrm{M}$ DTT, $100 \mu \mathrm{l}$ of biotin standard or unknown, and $550 \mu \mathrm{l}$ of assay buffer were incubated for $30 \mathrm{~min}$ with mixing. Then, $50 \mu \mathrm{l}$ of $4.63 \times 10^{-9} \mathrm{M}$ $\beta$-gal-biotin and $200 \mu \mathrm{l}$ of assay buffer were added, the solutions were mixed for $60 \mathrm{~min}$, and the particles were washed three times with $2 \mathrm{ml}$ of assay buffer. The particles were suspended in $100 \mu$ l of $0.034 \mathrm{M}$ ONPG solution and $800 \mu \mathrm{l}$ of assay buffer, and the solution 
was again incubated for $60 \mathrm{~min}$. The particles were removed, and the absorbance of the solution was measured at $415 \mathrm{~nm}$.

\subsection{Simultaneous vitamin $B_{12}$ and biotin assay}

Fifty $\mu \mathrm{l}$ of R-protein particles, $50 \mu \mathrm{l}$ of avidin particles, $50 \mu$ l of $0.672 \mathrm{M}$ DTT, $100 \mu$ l of vitamin $\mathrm{B}_{12}$ standard or unknown, $100 \mu \mathrm{l}$ of biotin standard or assay buffer, and $500 \mu \mathrm{l}$ of assay buffer were added. After incubating for $30 \mathrm{~min}, 50 \mu \mathrm{l}$ of $4.63 \times 10^{-9} \mathrm{M} \beta$-galbiotin and $4.00 \times 10^{-8} \mathrm{M}$ G6PDH-vitamin $\mathrm{B}_{12}$ solution along with $100 \mu \mathrm{l}$ of assay buffer were added, and the solutions were incubated for another $60 \mathrm{~min}$. After the particles were washed three times with $2 \mathrm{ml}$ aliquots of assay buffer, $100 \mu \mathrm{l}$ of $0.010 \mathrm{M} \mathrm{G6P}, 0.063 \mathrm{MNAD}$, and $0.034 \mathrm{M}$ ONPG solution and $800 \mu \mathrm{l}$ of assay buffer were added. The solutions were mixed for $60 \mathrm{~min}$, the solid phase was removed, and the absorbances of the solutions were determined at 347 and $415 \mathrm{~nm}$ via the diode array spectrophotometer. Alternately, similar results should be obtainable by sequential measurements of the supernatant at these same two wavelengths using a conventional UV-visible spectrophotometer.

\section{Results and discussion}

The enzymes G6PDH and $\beta$-gal were chosen for use as the labeling enzymes because they meet most of the requirements envisioned for the development of a successful simultaneous enzyme-linked binding assay system (see Introduction). $\beta$-Gal catalyses the conversion of ONPG to $o$-nitrophenol (ONP), while G6PDH converts NAD and G6P to NADH and 6-phosphogluconate. These substrates/products were chosen because they can be resolved spectrophotometrically. The wavelengths for measuring the enzymatic activities were determined based on the absorption spectra of the substrates and products. $o$-Nitrophenol production was monitored at $415 \mathrm{~nm}$ because no other species present absorbs at this wavelength. However, as shown in Fig. 1 , ONPG and ONP as well as NADH absorb in the region around $340 \mathrm{~nm}$ which is the usual wavelength for monitoring NADH. Fortunately, at $347 \mathrm{~nm}$ there is an isosbestic point in the absorbance spectra relating to the conversion of ONPG to ONP. Thus, NADH can be monitored at $347 \mathrm{~nm}$ independent of the concentrations

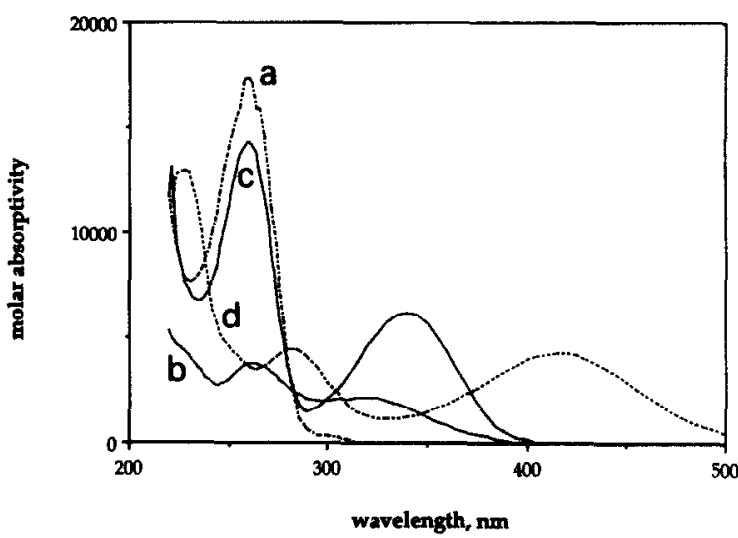

Fig. 1. Absorbance spectra of the substrates and products of the G6PDH and $\beta$-gal enzymatic reactions: (a) NAD, (b) NADH, (c) ONPG, and (d) ONP.

of ONPG or ONP within a reaction mixture with only a 4\% loss in signal for NADH detection (i.e., $\varepsilon_{347 \mathrm{~nm}}=5891$ and $\left.\varepsilon_{340 \mathrm{~nm}}=6106\right)$.

Both enzyme reactions were studied individually, and the reaction conditions were optimized for maximum enzyme activity when the reactions are run simultaneously. It is known that the presence of magnesium ions has little effect on the activity of G6PDH from $L$. mesenteroides [27] yet is required for optimal $\beta$-gal activity [28]. This was verified here by studies in which $\mathrm{Mg}^{2+}$ concentrations varied between $0-5 \mathrm{mM}$ resulted in no significant change in G6PDH activity; therefore, $2 \mathrm{mM} \mathrm{Mg}^{2+}$ was used for all subsequent enzyme assays. This level corresponds to the concentration of $\mathrm{Mg}^{2+}$ recommended for maximizing $\beta$-gal activity [28].

DTT is a common additive in $\beta$-gal activity assays since it acts as an acceptor alcohol thereby increasing the $\beta$-gal activity [28]. However, other reagents such as Tris- $\mathrm{HCl}$ can also act as activators of $\beta$-gal via the same mechanism [28]. Thus, little additional activation of the $\beta$-gal activity occurs when DTT is added to the Tris-HCl-based buffer (data not shown). Consequently, no DTT was added to the buffer in subsequent enzymatic determinations. However, as described below for vitamin assays, DTT is required in the buffer used during the initial sample/reagent incubation step of the single biotin and dual biotin/ $\mathbf{B}_{12}$ binding assay to prevent aggregation of the $\beta$-gal-biotin conjugate.

For a simultaneous enzyme-linked binding assay to be successful, conditions must be found in which the 


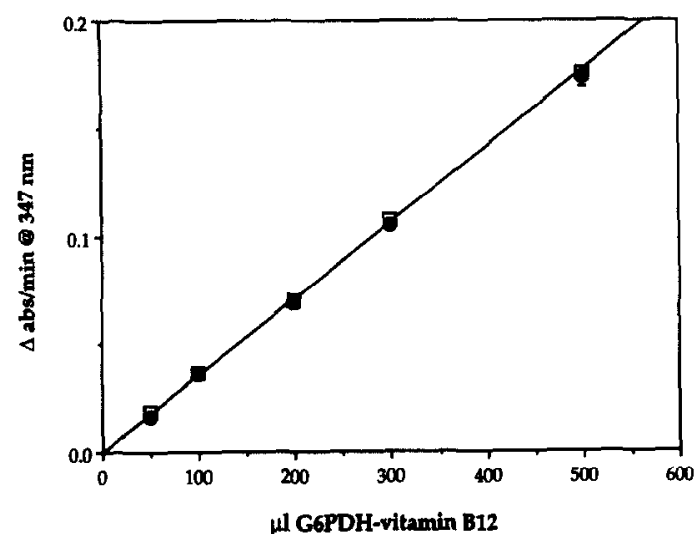

Fig. 2. Linearity of G6PDH activity for different amounts of $2.0 \times 10^{-9} \mathrm{M}$ G6PDH-vitamin $B_{12}$ conjugate in the presence of 100 $\mu l$ of $0.034 \mathrm{M}$ ONPG alone (O) and ONPG with $50 \mu \mathrm{l}$ of $4.63 \times 10^{-9} \mathrm{M} \beta$-gal-biotin conjugate ( $\square$ ). Data points are average of triplicate determinations with \pm S.D.

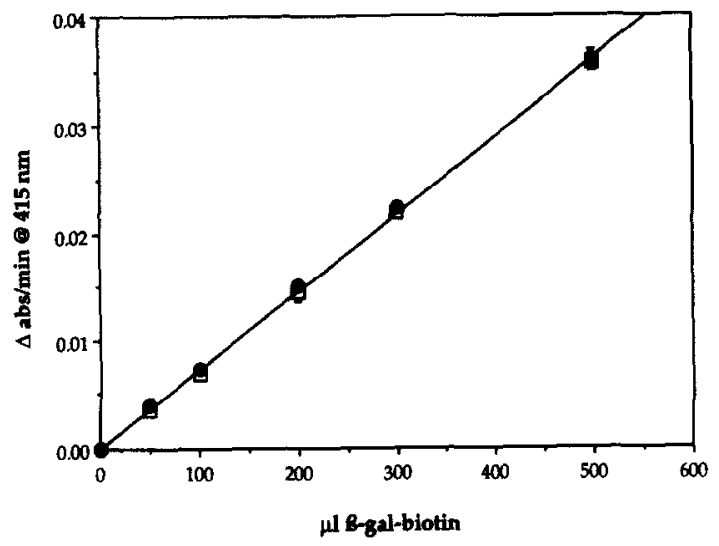

Fig. 3. Linearity of $\beta$-gal activity for different amounts of $4.63 \times 10^{-10} \mathrm{M} \beta$-gal-biotin conjugate in the presence of $100 \mu \mathrm{l}$ of $0.010 \mathrm{M}$ G6P and $0.063 \mathrm{M} \mathrm{NAD}(\odot)$ and G6P/NAD with $50 \mu \mathrm{l}$ of $2.0 \times 10^{-8} \mathrm{M}$ G6PDH-vitamin $B_{12}$ conjugate $(\square)$. Data points are average of triplicate determinations with \pm S.D.

Table 1

Kinetic constants of $\beta$-gal-biotin and G6PDH-vitamin $\mathbf{B}_{12}$ compared to the native enzymes

\begin{tabular}{lllll}
\hline Enzyme & substrate & $K_{\mathrm{M}}(\mu \mathrm{mol} / 1)$ & $k_{\text {cat }}\left(\min ^{-1}\right)$ & $k_{\text {cat }} / K_{\mathrm{M}}\left(\mathbf{M}^{-1} \min { }^{1}\right)$ \\
\hline$\beta$-gal & ONPG & 155 & $1.07 \times 10^{4}$ & $7.71 \times 10^{7}$ \\
$\beta$-gal-biotin & ONPG & 151 & $9.39 \times 10^{3}$ & $6.22 \times 10^{7}$ \\
G6PDH & G6P & 239 & $3.22 \times 10^{4}$ & $1.59 \times 10^{8}$ \\
& NAD & 333 & $3.53 \times 10^{4}$ & $1.29 \times 10^{8}$ \\
G6PDH- vitamin B 12 & G6P & 271 & $1.48 \times 10^{4}$ & $5.44 \times 10^{7}$ \\
& NAD & 345 & $1.66 \times 10^{4}$ & $4.67 \times 10^{7}$ \\
\hline
\end{tabular}

second enzyme-linked assay does not significantly affect the first. To determine the influence of a second enzyme reaction occurring simultaneously, the activity of $\beta$-gal and G6PDH were examined individually in the presence of all substrates as well as the other enzymatic reaction in the Tris- $\mathrm{HCl}, \mathrm{pH} 7.8$ assay buffer. It was found that both enzyme activities when present in the same mixture do not differ significantly from the activities when examined individually. This was confirmed by comparing the mean values for absorbance changes that occur over the range of $2.2-22 \mathrm{mU} / \mathrm{ml}$ of G6PDH in the presence and absence of $625 \mathrm{mU} / \mathrm{ml}$ of $\beta$-gal and $25-250 \mathrm{mU} / \mathrm{ml}$ of $\beta$-gal in the presence and absence of $55 \mathrm{mU} / \mathrm{ml}$ of G6PDH. Use of the $F$ test for each enzyme concentration, as well as a comparison of the slopes of the $\Delta A / \mathrm{min}$ values vs. enzyme activities added indicated that there is no statistical difference in the measured enzyme activities with and without the second enzyme reaction running simultaneously (at the 95\% confidence level) [29].

Based on these preliminary studies, a model assay for measuring biotin and vitamin $B_{12}$ was studied to demonstrate the dual simultaneous assay concept. The required $\beta$-gal-biotin and G6PDH-vitamin $B_{12}$ conjugates were prepared as described in the Experimental section. The enzyme conjugate activities were examined as above to determine whether conjugation of the enzymes results in reactions that are no longer independent of each other. As found for the native enzymes, the conjugated enzyme activities do not differ significantly when examined in the presence of all substrates or with the second enzyme reaction running simultaneously (see Figs. 2 and 3 ). In addition, the kinetic parameters of the enzyme conjugates were examined in detail and compared with the native enzymes. As Table 1 shows, there is very little change in these parameters; this was expected since there was only slight modification of the enzymes caused by the attachment 


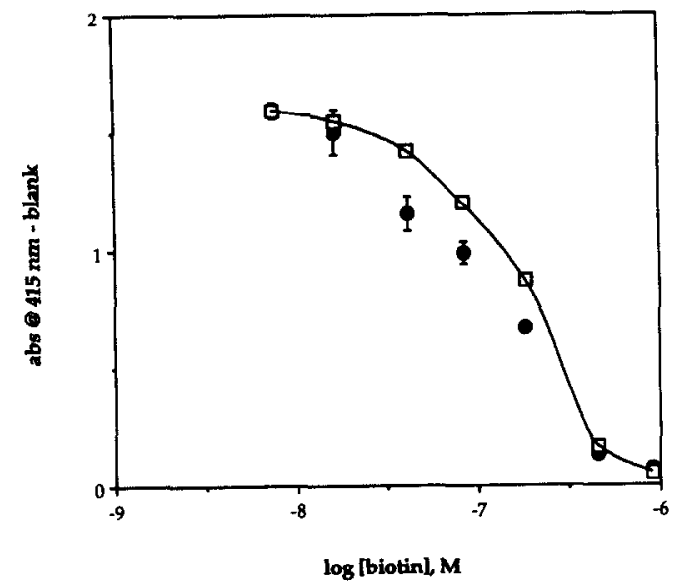

Fig. 4. Biotin dose-response curve in the absence ( $)$ and presence () of $50 \mu \mathrm{l}$ of $0.672 \mathrm{M} \mathrm{DTT}$.

of biotin and $B_{12}$ onto the respective enzymes (i.e., low ligand to enzyme ratios).

Detection limits for the simultaneous analysis of biotin and vitamin $B_{12}$ were not fully optimized here; they were set for the convenient determination of these compounds in vitamin tablets. The sequential incubation times employed ( $30 \mathrm{~min}$ for binding beads with sam$\mathrm{ple} /$ standard and $60 \mathrm{~min}$ with conjugates) were based on findings by Tsalta et al. [30] who used a G6PDHvitamin $\mathbf{B}_{12}$ conjugate and Sepharose-bound $\mathrm{R}$-protein to devise a solid-phase $B_{12}$ enzyme-linked binding assay. Indeed, preliminary studies indicated that the kinetics of the G6PDH-vitamin $\mathbf{B}_{12}$ conjugate binding to immobilized R-protein was slower than the reaction of $\beta$-gal-biotin with immobilized avidin. This might be expected based on the known higher affinity of the avidin/biotin reaction compared with the R-protein/ vitamin $B_{12}$ interaction (binding constants of $1.3 \times 10^{15}$ $\mathrm{M}^{-1}$ and $2.0 \times 10^{11} \mathrm{M}^{-1}$, respectively [31,32]).

During initial efforts to utilize the single biotin assay to determine biotin in vitamin preparations, it appeared that there was poor recovery of the biotin from the vitamin tablets. However, analysis of these same solutions by LC [33] revealed that biotin was present nearly in the same amount claimed by the manufacturers. Further studies demonstrated that the vitamin tablets were causing an apparent shift in the dose-response curve by increasing the amount of $\boldsymbol{\beta}$-gal-biotin conjugate bound to the solid phase, resulting in a shift of the dose-response curve to lower apparent biotin concen- trations. It is known that $\beta$-gal can form aggregates on standing in solution due to oxidation of free sulfhydryl groups to form intermolecular disulfide bonds. These aggregates can be dissociated by adding DTT or other reducing agents [27,34-36]. The vitamin tablets contain antioxidants (e.g., BHA and BHT) while the biotin standards do not. Thus, the presence of these antioxidants in the sample can dissociate the $\beta$-gal-biotin aggregates. By eliminating aggregation and thereby decreasing the size of the conjugate, more $\beta$-gal-biotin conjugate can bind to the solid phase (see Fig. 4 ). Thus, DTT was added to all solutions during the initial incubation period (but not during enzymatic determinations) to reduce this effect. DTT was found to have minimal effect on the G6PDH-vitamin $B_{12}$ conjugate under these conditions.

Typical dose-response curves obtained in the single and simultaneous formats for vitamin $\mathrm{B}_{12}$ and biotin assays are shown in Figs. 5 and 6, respectively. There is no change in the curve shape or detection range when the assays are performed in the single vs. simultaneous format. This confirms that there is no interference between the two sets of assay reagents. This is to be expected since both binding proteins are analyte-specific and both vitamins are structurally quite different.

The selectivity of the vitamin $B_{12} /$ biotin assay is comparable in both the single and simultaneous formats as demonstrated by the determination of the vitamin content in two different vitamin tablet formulations

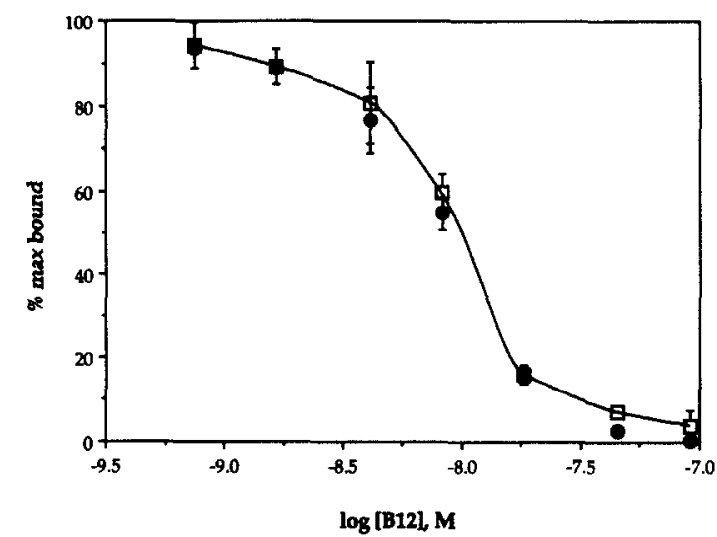

Fig. 5. Typical dose-response curve for vitamin $B_{12}$ detection using the G6PDH-vitamin $B_{12}$ conjugate $\left(2.0 \times 10^{-8} \mathrm{M}\right.$ in $50 \mu \mathrm{l}$ aliquot $)$ with the R-protein solid phase ( $50 \mu \mathrm{l}$ of $1: 20$ (packed bead $v / v$ )) in the single (O) and simultaneous $(\square)$ assay formats. Data points are the average of triplicate determinations with \pm S.D. 


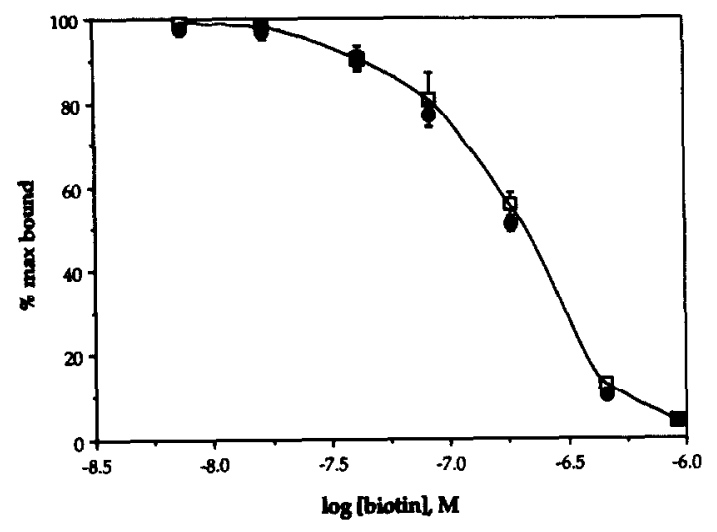

Fig. 6. Typical dose-response curve for biotin detection using the $\beta$ gal-biotin conjugate $\left(4.63 \times 10^{-9} \mathrm{M}\right.$ in $50 \mu$ laliquot) with the avidin solid phase $(50 \mu \mathrm{l}$ of $1: 20$ (packed bead $v / v))$ in the single $(\theta)$ and simultaneous $(\square)$ assay formats. Data points are the average of triplicate determinations with \pm S.D.

(see Table 2). These results indicated that even when vitamin $B_{12}$ and biotin are present at different concentrations, they can be measured with reasonable accuracy by the dual enzyme simultaneous binding assay. Indeed, biotin and $\mathrm{B}_{12}$ levels obtained for the same two preparations via LC methods [33,37] are in good agreement with the values determined by both the single and simultaneous enzyme-linked binding assay methods (see Table 2). Recovery studies for vitamin $B_{12}$ and biotin were also performed by spiking vitamin tablets with different amounts of the vitamins to be analyzed. As shown in Table 3, the added vitamins can be recovered with acceptable accuracy given the low levels added. It should be noted that for all tablet measurements, the analytical determinations were made using graphical estimations from the non-linear doseresponse curves. More accurate analysis could likely be accomplished by fitting the dose-response curve
Table 3

Recovery study for determining biotin and vitamin $B_{12}$ in multivitamin tablet using single and simultaneous assay format

\begin{tabular}{llll}
\hline Vitamin & Added, $\mu \mathrm{g}$ & \multicolumn{2}{l}{ Found * } \\
\cline { 3 - 4 } & & Single & Simultaneous \\
\hline Biotin & 30 & $35 \pm 7$ & $25 \pm 2$ \\
& 90 & $94 \pm 6$ & $77 \pm 8$ \\
Vitamin $\mathbf{B}_{12}$ & 6.0 & $7.8 \pm 1.1$ & $5.0 \pm 0.7$ \\
& 18 & $17 \pm 3$ & $18 \pm 1$ \\
\hline
\end{tabular}

Average of triplicate determinations.

data to an appropriate equation describing such competitive binding curves.

In summary, we have shown that the activities of $\beta$ gal and G6PDH can be measured accurately in a simultaneous format without interference from the second enzymatic reaction. In the case where two binding proteins are analyte-specific, it is possible to assay both analytes simultaneously using $\beta$-gal and G6PDH as dual labeling enzymes. This simultaneous enzymelinked binding assay offers the potential to determine the concentrations of two analytes occurring in a single reaction mixture. While applied here for the model analytes vitamin $B_{12}$ and biotin, this same dual enzyme system could be used for the simultaneous detection of drugs using anti-drug antibodies, or in sandwich-type enzyme immunoassays for simultaneous measurements of two proteins (using Ab-enzyme conjugates). In addition, it may be possible to extend this concept to the development of more rapid simultaneous homogeneous enzyme-linked assays. Such work is currently in progress in this laboratory.

Table 2

Analysis of vitamin tablets for biotin and vitamin $B_{12}$ using both single and simultaneous assay formats

\begin{tabular}{llllll}
\hline Analyte & Sample & Claimed, $\mu \mathrm{g} /$ tablet & Claimed, single & Found ${ }^{\mathrm{a}}$, simultaneous & Found, LC $^{\mathrm{b}}$ \\
\hline Biotin & Multivitamin & 30 & $31 \pm 3$ & $25 \pm 4$ & $25.8 \pm 1.5$ \\
& B-Complex & 100 & $111 \pm 31$ & $115 \pm 13$ & $85.8 \pm 8.6$ \\
Vitamin $\mathrm{B}_{12}$ & Multivitamin & 6 & $6.4 \pm 0.8$ & $5.7 \pm 0.4$ & $6.5 \pm 0.2$ \\
& B-Complex & 100 & $103 \pm 15$ & $109 \pm 13$ & $93.8 \pm 3.9$ \\
\hline
\end{tabular}

average of triplicate determinations.

${ }^{\mathrm{b}}$ Using methods reported in Refs. [33] and [37]. 


\section{Acknowledgements}

We gratefully acknowledge the National Science Foundation for supporting this work (CHE 9119728).

\section{References}

[1] E. Engvall and P. Perlmann, Immunochemistry, 8 (1971) 871.

[2] B.K. VanWeemen and A.H.W.M. Schuurs, FEBS Lett., 15 (1971) 232.

[3] A. Johannsson, C.P. Price and D.J. Newman (Eds.), in Principles and Practice of Immunoassay, Stockton Press, New York, 1991, p. 265.

[4] L.G. Bachas, C.D. Tsalta and M.E. Meyerhoff, BioTechniques, 4 (1986) 42.

[5] G.S. Cha and M.E. Meyerhoff, Anal. Biochem., 168 (1988) 216.

[6] S. Daunert, L.G. Bachas and M.E. Meyerhoff, Anal. Chim. Acta, 208 (1988) 43.

[7] L.J. Kricka, Clin. Chem., 38 (1992) 327.

[8] R. Ekins and F. Chu, Clin. Chem., 39 (1993) 369.

[9] S. Gutcho and L. Mansbach, Clin. Chem., 23 (1977) 1609.

[10] W.R. Whigham and L. Sudarsanan, Clin. Chem., 23 (1977) 1778.

[11] S.E. Kakabakos, T.K. Christopoulos and E.P. Diamandis, Clin. Chem., 38 (1992) 338.

[12] C. Blake, M.N. Al-Bassam, B.J. Gould, V. Marks, J.W. Bridges and C. Riley, Clin. Chem., 28 (1982) 1469.

[13] A.H.W.M. Schuurs and B.K. VanWeemen, Clin. Chim. Acta, 81 (1977) 1.

[14] G.B. Wisdom, Clin. Chem., 22 (1976) 1243.

[15] M.J. O'Sullivan, Anal. Proc. (London), 18 (1981) 104.

[16] J.B. Armitage, J.R. Cannon, A.W. Johnson, L.F.J. Parker, E.L. Smith, W.H. Stafford and A.R. Todd, J. Chem. Soc., 75 (1953) 3849 .
[17] D.L. Anton, H.P.C. Hogenkamp, T.E. Walker and N.A. Matwiyoff, J. Am. Chem. Soc., 102 (1980) 2215.

[18] R. Grasbeck, in B. Zagalak and W. Friedrich (Eds.), Vitamin $B_{12}$, Walter de Gruyter, New York, 1979, p. 743.

[19] J.F. Kolhouse, H. Kondo, N.C. Allen, E. Poddell and R.H. Allen, N. Engl. J. Med. 299 (1978) 785.

[20] J.F. Kolhouse and R.H. Allen, J. Clin. Invest., 60 (1977) 1381.

[21] C.D. Tsalta and M.E. Meyerhoff, Anal. Chem., 59 (1987) 837.

[22] G.W. Anderson, J.E. Zimmerman and F.M. Callahan, J. Am. Chem. Soc., 86 (1964) 1839.

[23] M.C. Carter and M.E. Meyerhoff, J. Immunol. Methods, 81 (1985) 245.

[24] E.A. Bayer, M.G. Zalis and M. Wilchek, Anal. Biochem., 149 (1985) 529

[25] O. Livnah, E.A. Bayer, M. Wilchek and J.L. Sussman, Proc. Natl. Acad. Sci. USA, 90 (1993) 5076.

[26] Affinity Chromatography, Principles and Methods, Pharmacia Fine Chemicals, Piscataway, NJ, 1979.

[27] C. Olive and H.R. Levy, Methods Enzymol., 41 (1975) 196.

[28] K. Wallenfels and R. Weil, in P.D. Boyer (Ed.), The Enzymes, Vol. 7, Academic Press, New York, 1972, p. 617.

[29] M. Hamburg, Basic Statistics: A Modern Approach, Harcourt Brace Jovanovich, Chicago, 1979.

[30] C.D. Tsalta, S.A. Rosario, G.S. Cha, L.G. Bachas and M.E. Meyerhoff, Mikrochim. Acta, 1 (1989) 65.

[31] N.M. Green, Adv. Protein Chem., 29 (1975) 85.

[32] E. Hippe and H. Olesen, Biochim. Biophys. Acta, 243 (1971) 83.

[33] S.L. Crivelli, P.F. Quirk, D.J. Steible and S.P. Assenza, Pharm. Res., 4 (1987) 261.

[34] H. Sund and K. Weber, Biochem. Z., 337 (1963) 24.

[35] K. Wallenfels, M.L. Zarnitz, G. Laule, H. Bender and M. Keser, Biochem. Z., 331 (1959) 459.

[36] S.R. Rohlfing and I.P. Crawford, J. Bacteriol., 91 (1966) 1085.

[37] J. Dalbacke and I. Dahlquist, J. Chromatogr., 541 (1991) 383. 